\title{
PREVALENCE OF PROSTATE CANCER AT SERUM PSA LEVEL BETWEEN 2.5 AND 4.0 NG/ML IN BANGLADESHI MEN
}

\author{
MD. LATIFUR RAHMAN MIAH ${ }^{1}$, MD. SHAWKAT ALAM ${ }^{1}$, MD. ABDUS SALAM ${ }^{1}$, MD. NAUSHAD ALAM ${ }^{1}$, \\ MD. NAZMUL ISLAM ${ }^{1}$, SUDIP DAS GUPTA ${ }^{2}$
}

${ }^{1}$ Department of Urology, National Institute of Kidney Diseases \& Urology, Dhaka, ${ }^{2}$ Department of Urology, Sir Salimullah Medical College, Dhaka.

\begin{abstract}
Background: Prostate cancer is the most common cancer in men. The most common prostate cancer test is the prostate-specific antigen (PSA) test. This is a simple blood test that measures the presence of prostate-specific antigen circulating in bloodstream. This test is usually the first step in any prostate cancer diagnosis.

Objective: To detect the occurrence of prostate cancer at different level of serum PSA level between $2.5 \mathrm{ng} / \mathrm{ml}$ and $4 \mathrm{ng} / \mathrm{ml}$.

Method: This hospital based cross sectional analytical study was conducted between the periods of January 2012 to April 2013. A total of 30 patients with features of lower urinary tract symptoms with enlarged prostate attending to the Department of Urology, National Institute of Kidney Diseases \& Urology (NIKDU), Sher-E-Bangla Nagar, Dhaka were purposively selected as study population by taking the permission of ethical committee. Patients more than 50 years old with lower urinary tract symptoms at S. PSA level 2.5 - 4 $\mathrm{ng} / \mathrm{ml}$ and enlarged prostate in DRE were selected as study population. Patients with bleeding disorder, anorectal pathology, active UTI or prostatitis or urethral stricture were excluded from this study. DRE was done to see the size, consistency and nodularity of prostate. Those who had enlarged prostate found on DRE, they were sent for biopsy multi parametric MRI (MPMRI) \& Prostate Imaging Reporting and Data system (PIRAD) score may be applied.
\end{abstract}

Result: The mean age of the patients was $66.87 \pm 10.13$ years with a range of 52-90 years. Among 30 patients 10 (33.3\%) were in the age group of 51-60 years, 10 (33.3\%) were in the age group of 61 - 70 years, $5(16.7 \%)$ were in the age group of 71 - 80 years and 5 $(16.7 \%)$ were in the age group $>80$ years. Among 30 patients $4(13.3 \%)$ had malignant lesion and 26 (86.7\%) had benign lesion. Mean serum PSA level among the patients with histopathological findings benign and malignant were $3.34 \pm 0.51$ and $3.47 \pm 0.43 \mathrm{ng} / \mathrm{ml}$ respectively. Out of 4 patients with malignant lesion, 1(25.0\%) had serum PSA level within 2.50-2.99 $\mathrm{ng} / \mathrm{ml}$, another 1(25.0\%) had 3.00-3.49 $\mathrm{ng} / \mathrm{ml}$ and 2(50.0\%) had serum $P S A$ level within $3.50-4.00 \mathrm{ng} / \mathrm{ml}$. There is no statistically significant difference observed in serum PSA level among the patients with histopathological findings benign and malignant $(P>0.05)$.

Conclusion: For early diagnosis of prostate cancer cut-off value of serum PSA of $2.5 \mathrm{ng} /$ $\mathrm{ml}$ may be used as an indication for prostate biopsy.

Key words: Prostate cancer, PSA (prostate-specific antigen), cut-off value, prostate Bangladesh J. Urol. 2016; 19(2): 85-89

Address of correspondence: Dr. Md. Latifur Rahman Miah, Assistant Professor, Department of Urology, National Institute of Kidney Diseases and Urology, Sher-e-Banglanagar, Dhaka. 


\section{Introduction}

Worldwide, prostate cancer (PCa) is the fourth most common cancer in men with incidence and mortality rates that vary markedly among and within different countries[1]. The highest incidence of $\mathrm{PCa}$ is in the Western world and the lowest in Asian countries[2]. PCa is the most common malignancy in males and the second leading cause of male cancer death in the United States. The estimated lifetime risk of disease is $17.6 \%$ for whites and $20.6 \%$ for African Americans, with a lifetime risk of death of $2.8 \%$ and $4.7 \%$ respectively[3]. Despite decades of research, there is no reasonable prospect that prostate cancer can be cured once it has metastasized. The greatest hope of reducing prostate cancer mortality is therefore through early detection and prevention. Moreover, because no important carcinogen or modifiable risk factor has been identified, prevention of prostate cancer is largely a matter of early detection [4].

Prostate cancer is uncommon before the age of 50 years, till its frequency climbs steeply with age to peak or plateau upto the 9th decade for both incidence and mortality rate. [5] Unfortunately, the disease is uniformly fatal once the tumour metastasizes outside the gland. But if diagnosed early, surgery provides excellent results with regard to local disease control and the prospect for long-term, disease-free survival. In the absence of effective treatment options for advanced prostate cancer, intensive efforts to detect low stage, curable cancers may help to improve prostate cancer-specific survival[6].

Digital rectal examination (DRE) has been used for diagnosis and screening for prostate cancer since the early 1900s, and its importance is well-established[7]. But there remain a considerable number of prostate cancer not detectable by rectal examination even in the presence of symptomatic disease.

One of the most important diagnostic tools used to detect prostate cancer is PSA, yet increased PSA alone does not reflect the presence of prostate cancer. Other pathological prostatic conditions such as prostatitis and benign prostatic hyperplasia (BPH) may also increase the level of PSA. However, unlike in other prostate diseases, PSA has a key role in the diagnosis and management of prostate cancer[2]. Prostate imaging reporting and data system (PIRAD score) refers to a structured reporting scheme for evaluating the prostate for prostate cancer.

The widespread use of serum Prostate Specific Antigen testing has increased proportion of early stage cancers detection and partially responsible for the recent decrease in prostate cancer mortality rates in the United States. A PSA cutoff of $4 \mathrm{ng} / \mathrm{ml}$ is generally used for recommending a biopsy[8]. Multi parametric MRI (MPMRI) can detect specific cancer cells from prostatic nodules in any where even in anterior \& central zone of prostate. This fusion biopsy has higher cancer detection rate than USG.

According to a study, cancer is detected in initial or early follow-up biopsies in more than one third of man with PSA levels $>4 \mathrm{ng} / \mathrm{ml}[9]$. It is informative that cancer cells $(\mathrm{CaP})$ liberate 10 times more PSA than benign cells $(\mathrm{BPH})$ due to lack of basement membrane [6].

Traditionally normal level of recommending serum PSA $0-4 \mathrm{ng} / \mathrm{ml}$ but no identifiable PSA level guarantees normalcy. Carcinoma prostate may be found in S. PSA level "0" on the contrary, carcinoma prostate may not be found even in S. PSA level "100"[10]. But it is remarkable that high S. PSA causes relatively increased risk of carcinoma prostate and it must be proved by prostate biopsy. Initially, a threshold of $4.0 \mathrm{ng} / \mathrm{ml}$ was the recommended level at which a man should undergo prostate biopsy. A level between $4.0-10 \mathrm{ng} / \mathrm{ml}$ thinks to be "diagnostic gray zone" [11]. Conventionally cut-off value has taken as $4.0 \mathrm{ng} / \mathrm{ml}$. Using the cut-off value of $4.0 \mathrm{ng} / \mathrm{ml}$, the sensitivity, specificity and PPV were $89.88 \% 37 \%$ \& $49 \%$ respectively. [10] By raising the cut-off value to $10 \mathrm{ng} / \mathrm{ml}$ increases the specificity and PPV to $66 \%$ and $63 \%$ respectively, while the sensitivity is reduced to $83.7 \%$ [10] .

It has recently been suggested that the diagnostic threshold for the prostate specific antigen (PSA) assay be lowered to enhance prostate cancer detection. A22\% incidence of prostate cancer has been reported in men with PSA between 2.5 and $4.0 \mathrm{ng} / \mathrm{ml}$ (Babaian et al. 2001) [12] .

Prostate cancer is not uncommon in Bangladesh. Therefore, present study is designed to determine occurrence of prostate cancer at serum PSA between $2.5 \mathrm{ng} / \mathrm{ml}$ and $4 \mathrm{ng} / \mathrm{ml}$ which will help to find out a new 
cut-off value for early diagnosis, effective treatment, increase survival and decrease disease specific mortality.

\section{Method:}

This hospital based cross sectional analytical study was conducted between the periods of January 2012 to April 2013 in the Department of Urology, National Institute of Kidney Diseases \& Urology (NIKDU), Sher-e-Bangla Nagar, Dhaka. By taking informed written consent a total of 30 patients with features of lower urinary tract symptoms with enlarged prostate attending to Department of Urology, National Institute of Kidney Diseases \& Urology (NIKDU), Sher-e-Bangla Nagar, Dhaka were purposively selected as study population. Patients more than 50 years old with lower urinary tract symptoms at S. PSA level $2.5-4 \mathrm{ng} / \mathrm{ml}$ and enlarged prostate in DRE were selected as study population. Patients with bleeding disorder, anorectal pathology, active UTI or prostatitis or urethral stricture were excluded from this study. After proper counseling and consent, DRE was done to see the size, consistency and nodularity of prostate. Those who had enlarged prostate found on DRE, they were sent for TRUS (Trans rectal Ultrasonogram) guided biopsy. Before taking biopsy patients were again judged by inclusion and exclusion criteria.

\section{Results:}

The mean age of the patients was $66.87 \pm 10.13$ years with a range of 52-90 years. Among 30 patients 10 $(33.3 \%)$ were in the age group of $51-60$ years, 10 (33.3\%) were in the age group of 61 - 70 years, $5(16.7 \%)$ were in the age group of $71-80$ years and $5(16.7 \%)$ were in the age group $>80$ years (Table I).
Table I

Distribution of patients by age group $(n=30)$

\begin{tabular}{lcc}
\hline Age(Year) & Frequency & Percentage \\
\hline $51-60$ & 10 & 33.3 \\
$61-70$ & 10 & 33.3 \\
$71-80$ & 05 & 16.7 \\
$>80$ & 05 & 16.7 \\
\hline Total & 30 & 100.0 \\
\hline
\end{tabular}

Mean \pm SD (Range)66.87 $\pm 10.13(52-90)$

Among 30 patients $4(13.3 \%)$ had malignant lesion and $26(86.7 \%)$ had benign lesion. (Table II).

Table II

Distribution of patients by histopathological findings $(n=30)$

\begin{tabular}{lcc}
\hline Histopathological finding & Frequency & Percentage \\
\hline Benign & 26 & 86.7 \\
Malignant & 4 & 13.3 \\
\hline
\end{tabular}

Mean serum PSA level among the patients with histopathological findings benign and malignant were $3.34 \pm 0.51$ and $3.47 \pm 0.43 \mathrm{ng} / \mathrm{ml}$ respectively. There was no statistically significant difference observed in mean serum PSA level among the patients with histopathological findings benign and malignant $(P>0.05)$. Out of 4 patients with malignant lesion, $1(25.0 \%)$ had serum PSA level within $2.50-2.99 \mathrm{ng} / \mathrm{ml}$, another $1(25.0 \%)$ had $3.00-3.49 \mathrm{ng} / \mathrm{ml}$ and $2(50.0 \%)$ had serum PSA level within $3.50-4.00 \mathrm{ng} / \mathrm{ml}$. There is no statistically significant difference observed in serum PSA level among the patients with histopathological findings benign and malignant $(P>0.05)$.

Table III

Distribution of patients by histopathological finding and serum PSA level $(n=30)$

\begin{tabular}{|c|c|c|c|c|}
\hline \multirow[t]{2}{*}{ Serum PSA level (ng/ml) } & \multicolumn{2}{|c|}{ Histopathology } & \multirow[t]{2}{*}{ Total } & \multirow[t]{2}{*}{ p value } \\
\hline & Benignn (\%) & Malignantn (\%) & & \\
\hline $2.50-2.99$ & $09(34.6)$ & $1(25.0)^{\#}$ & $10(33.3)$ & \\
\hline $3.00-3.49$ & $04(15.4)$ & $1(25.0)$ & $05(16.7)$ & \\
\hline $3.50-4.00$ & $13(50.0)$ & $2(50.0)$ & $15(50.0)$ & \\
\hline Total & $26(100.0)$ & $4(100.0)$ & $30(100.0)$ & \\
\hline Mean \pm SD & $3.34 \pm 0.51$ & $3.47 \pm 0.43$ & $3.35 \pm 0.50$ & 0.625 \\
\hline
\end{tabular}

$t$ test is done to measure the level of significance 


\section{Discussion:}

Prostate cancer $(\mathrm{PCa})$ is the most common urological malignancy in males and incidence of PCa varies from country to country[2]. One of the most important diagnostic tools used to detect prostate cancer is PSA, yet increased PSA alone does not reflect the presence of prostate cancer[2]. This non-invasive serological test has tasted a new light in the diagnosis of prostate cancer. The value of S. PSA as a tumour marker is limited by the fact that it is organ-specific rather than cancer-specific and there appears to be no non-invasive accurate means of distinguishing an elevated PSA secondary to nodular hyperplasia from that due to PCa. Other pathological prostatic conditions such as prostatitis and benign prostatic hyperplasia $(\mathrm{BPH})$ may also increase the level of PSA. However, unlike in other prostate diseases, S. PSA has a key role in the diagnosis and management of prostate cancer [2].

The present study conducted to find out the occurrence of prostate cancer at different level of serum PSA between 2.5 and d" $4 \mathrm{ng} / \mathrm{ml}$. It also examined the histopathological characteristics of detected cancer in different levels of S. PSA values between $2.5 \mathrm{ng} / \mathrm{ml}$ and $4 \mathrm{ng} / \mathrm{ml}$. Total 30 patients were included in the present study.

In the present study, the mean age of the patients was $66.87 \pm 10.13$ years with a range of 52 to 90 years. Among 30 patients one third $(33.3 \%)$ were in the age group of $51-60$ years, another one third (33.3\%) were in the age group of 61 to 70 years, $5(16.7 \%)$ were in the age group of 71 to 80 years and $5(16.7 \%)$ were in the age group $>81$ (Table I). Babaian et al in their study reported the median age of men with cancer was 62 years (range 43 to 74)[12].

Among 30 patients $4(13.3 \%)$ had malignant lesion and $26(86.7 \%)$ had benign lesion. (Table II).

Mean serum PSA level among the patients with histopathological findings benign and malignant were $3.34 \pm 0.51$ and $3.47 \pm 0.43 \mathrm{ng} / \mathrm{ml}$ respectively. There was no statistically significant difference observed in mean serum PSA level among the patients with histopathological findings benign and malignant $(P>0.05)$. Out of 4 patients with malignant lesion, $1(25.0 \%)$ had serum PSA level within $2.50-2.99 \mathrm{ng} / \mathrm{ml}$, another $1(25.0 \%)$ had $3.00-3.49 \mathrm{ng} / \mathrm{ml}$ and $2(50.0 \%)$ had serum PSA level within $3.50-4.00 \mathrm{ng} / \mathrm{ml}$. There is no statistically significant difference observed in serum PSA level among the patients with histopathological findings benign and malignant ( $P>0.05)$ (Table III). According to a study by Shekariz et al. cancer is detected in initial or early follow-up biopsies in more than one third of man with PSA levels $>4 \mathrm{ng} / \mathrm{ml}[9]$.

The widespread use of serum Prostate Specific Antigen testing has increased proportion of early stage cancers detection and partially responsible for the recent decrease in prostate cancer mortality rates in the United States. A S. PSA cut-off of $4 \mathrm{ng} / \mathrm{ml}$ is generally used for recommending a biopsy[8]. It is informative that cancer cells $(\mathrm{CaP})$ liberate 10 times more PSA than benign cells $(\mathrm{BPH})$ due to lack of basement membrane[6]. In the present study mean serum PSA level among the patients with histopathological findings benign and malignant were $3.34 \pm 0.51$ and $3.47 \pm 0.43 \mathrm{ng} / \mathrm{ml}$ respectively. There is no statistically significant difference observed in mean serum PSA level among the patients with histopathological findings benign and malignant $(P>0.05)$. Out of 26 patients with benign lesion, 9 (34.6\%) had serum PSA level within $2.50-2.99 \mathrm{ng} / \mathrm{ml}, 4(15.4 \%)$ had $3.00-3.49 \mathrm{ng} / \mathrm{ml}$ and $13(50.0 \%)$ had serum PSA level within $3.50-4.00 \mathrm{ng} / \mathrm{ml}$. Out of 4 patients with malignant lesion, $1(25.0 \%)$ had serum PSA level within $2.50-2.99 \mathrm{ng} / \mathrm{ml}$, another $1(25.0 \%)$ had $3.00-3.49 \mathrm{ng} /$ $\mathrm{ml}$ and 2(50.0\%) had serum PSA level within 3.50-4.00 $\mathrm{ng} / \mathrm{ml}$. There is no statistically significant difference observed in serum PSA level among the patients with histopathological findings benign and malignant $(P>0.05)$ (Table IV). According to a study by Shekariz et al. cancer is detected in initial or early follow-up biopsies in more than one third of man with PSA levels $>4 \mathrm{ng} / \mathrm{ml}[9]$. Rashid et al. in a study recommended that for early diagnosis of prostate cancer cut-off value of serum PSA of $2.5 \mathrm{ng} / \mathrm{ml}$ can be an indication for prostate biopsy[13]. Babaian et al. in their study reported that a significant incidence of cancer $(24.5 \%, 37$ of 51$)$ in men with serum PSA between 2.5 and $4.0 \mathrm{ng} / \mathrm{ml}[12]$.

\section{Conclusion:}

The more S. PSA testing, the more will be the diagnosis of low stage disease and lower the prostate cancer death rate. In this study, $13.3 \%$ of prostate cancer cases could be missed if serum PSA level $4 \mathrm{ng} / \mathrm{ml}$ was taken as cut off value. For early diagnosis of prostate cancer serum PSA level $2.5 \mathrm{ng} / \mathrm{ml}$ may be used as an indication for prostate biopsy. PSA screening has lead to a substantial increased in the diagnosis of incidence of prostate cancer. This increased detection rate of diagnosis of prostate cancer has caused to decrease the advanced stage disease at a dramatic rate. 


\section{References:}

1. Reiter RE, de Kernion JB. Epidemiology, etiology and prevention of prostate cancer. In: Walsh Patrick C, RetikAlan B, E Darracott Vaughan, Alan J Wein [editors]: Campbell's Urology. 8th ed. Philadelphia: Saunders; 2002; 3003-3024.

2. Mochtar CA and Andika RS. The value of prostatespecific antigen in Asia. Ther Adv Urol. 2010;2(2): 77-83.

3. Presti JC Jr, Tanagho EA. Disorders of bladder, prostate and seminal vesicles. In: Emil A Tanagho, Jack W McAninch [editors]: Smith's General Urology, 16th ed. New York: Lange medical book / McGraw Hill; 2004. 576-591.

4. Vickers AJ, Lilja H. Predicting prostate cancer many years before diagnosis: how and why? World journal of urology. 2012 Apr 1;30(2):131-5.

5. Gilligan T, Wang PS, Levin R, Kantoff PW, Avorn $J$. Racial differences in screening for prostate cancer in the elderly. Archives of internal medicine. 2004 Sep 27;164(17):1858-64.

6. Polascik TJ, Oesterling JE, Partin AW. Prostate specific antigen: a decade of discovery-what we have learned and where we are going. The Journal of urology. 1999 Aug 31;162(2):293-306.

7. Carter HB, Epstein JI, Partin AW. Influence of age and prostate-specific antigen on the chance of curable prostate cancer among men with nonpalpable disease. Urology. 1999 Jan 31;53(1):126-30.
8. Catalona WJ, Hudson MA, Scardino PT, Richie JP, Ahmann FR, Flanigan RC, et al. Selection of optimal prostate specific antigen cutoffs for early detection of prostate cancer: receiver operating characteristic curves. Urol. 1994; $152(6$ Pt 1): 2037-42.

9. Shekarriz B, Upadhyay J, Bianco FJ, Tefilli MV, Tiguert R, Gheiler EL, Grignon DJ, Pontes JE, Wood DP. Impact of preoperative serum PSA level from 0 to $10 \mathrm{ng} / \mathrm{ml}$ on pathological findings and disease free survival after radical prostatectomy. The Prostate. 2001 Aug 1;48(3):136-43

10. Chavan SV, Chavan NR, Balaji A, Trivedi VD, Chavan PR. A pilot study on the use of serum glyoxalase as a supplemental biomarker to predict malignant cases of the prostate in the PSA range of $4-20 \mathrm{ng} / \mathrm{ml}$. The Indian journal of medical research. 2011 Oct 1;134(4):458.

11. Amayo A and Obara W. Serum prostate specific antigen levels in men with benign prostatic hyperplasia and cancer of prostate, The East African Medical Journal. 2004;81( 1):22-26

12. Babaian RJ, Johnston DA, Naccarato W. The incidence of prostate cancer in a screening population with a serum prostate specific antigen between 2.5 and $4.0 \mathrm{ng} / \mathrm{ml}$ : relation to biopsy strategy. J Urol. 2001;165:757-760.

13. Rashid MM, Alam AKMK, Habib AKMK, Rahman $\mathrm{H}$, Hossain AKMS, Salam MA, et al. Efficacy of lower cut off value of serum prostate specific antigen in diagnosis of prostate cancer. Bangladesh Med Res Counc Bull. 2012;38: 90-93. 